\title{
Sinergism among auxins, gibberellins and cytokinins in tomato cv. Micro-Tom
}

\author{
Stella C Cato ${ }^{1}$; Willian R Macedo² Lázaro Eustáquio P Peres $^{2}$; Paulo Roberto de C e Castro ${ }^{2}$

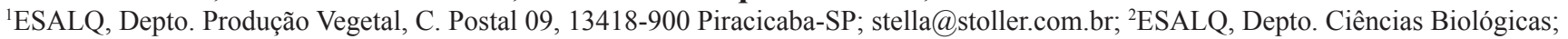 \\ willian_rmacedo@yahoo.com.br; lazaropp@esalq.usp.br; prcastro@esalq.usp.br.
}

\begin{abstract}
The aim of this study was to evaluate the effect of isolated and combined applications of gibberellic acid (gibberellin), indolbutyric acid (auxin) and kinetin (cytokinin) on vegetative and reproductive development of tomato test plants (Solanum lycopersicum cv. MicroTom), to better elucidate the interactions among these hormonal classes. The following treatments were accomplished through foliar application: $\mathrm{GA}_{3}\left(5 \mathrm{mg} \mathrm{L}^{-1}\right)$; IBA $\left(5 \mathrm{mg} \mathrm{L}^{-1}\right) ; \mathrm{KIN}\left(9 \mathrm{mg} \mathrm{L}^{-1}\right) ; \mathrm{GA}_{3}+$ IBA ( $\left.5 \mathrm{mg} \mathrm{L}^{-1}+5 \mathrm{mg} \mathrm{L}^{-1}\right) ; \mathrm{GA}_{3}+\mathrm{KIN}\left(5 \mathrm{mg} \mathrm{L}^{-1}+9 \mathrm{mg} \mathrm{L}^{-1}\right) ; \mathrm{IBA}+$ $\mathrm{KIN}\left(5 \mathrm{mg} \mathrm{L}^{-1}+9 \mathrm{mg} \mathrm{L}^{-1}\right) ; \mathrm{GA}_{3}+\mathrm{IBA}+\mathrm{KIN}\left(5 \mathrm{mg} \mathrm{L}^{-1}+5 \mathrm{mg} \mathrm{L}^{-1}+\right.$ $\left.9 \mathrm{mg} \mathrm{L}^{-1}\right)$ and Stimulate ${ }^{\circledR}\left(100 \mathrm{~mL} \mathrm{~L}^{-1}\right)$. Plants from the control were sprayed with water. Stimulate ${ }^{\circledR}$, is a commercial liquid formulation containing KIN (90 $\left.\mathrm{mg} \mathrm{L}^{-1}\right), \mathrm{GA}_{3}\left(50 \mathrm{mg} \mathrm{L}^{-1}\right)$ and IBA $\left(50 \mathrm{mg} \mathrm{L}^{-1}\right)$. We analyzed the shoot dry matter $(\mathrm{g})$, root dry matter $(\mathrm{g})$; fruit fresh matter $(\mathrm{g})$; fruit dry matter $(\mathrm{g})$ and fruit size $(\mathrm{cm})$. The experimental design was completely randomized with nine treatments and fifteen replications. The treatment means were compared by Tukey's test. Some combined applications of $\mathrm{GA}_{3}$, IBA and KIN or Stimulate ${ }^{\circledR}$ promoted significant increases in the dry matter accumulation of roots and fresh and dry matter of fruit compared to the control. Besides the perspective to extend such results for commercial tomato production, the relevance of known hormonal interactions for the results obtained is discussed.
\end{abstract}

Keywords: Solanum lycopersicum, hormonal balance, plant regulators, hormonal interactions.

\section{RESUMO}

\section{Sinergismo entre auxinas, giberelinas e citocininas em tomate cv. Micro-Tom}

Neste trabalho objetivou-se avaliar o efeito da aplicação isolada e combinada do ácido giberélico (giberelina), ácido indolbutírico (auxina) e cinetina (citocinina) sobre o desenvolvimento vegetativo e reprodutivo de plantas teste de tomateiro (Solanum lycopersicum cv. Micro-Tom), para elucidar as interações entre essas classes hormonais. Através de pulverização foliar, os seguintes tratamentos foram realizados: ácido giberélico $\left(5 \mathrm{mg} \mathrm{L}^{-1}\right)$; ácido indolbutírico (5 $\left.\mathrm{mg} \mathrm{L}^{-1}\right)$; cinetina ( $\left.9 \mathrm{mg} \mathrm{L}^{-1}\right)$; ácido giberélico + ácido indolbutírico (5 $\left.\mathrm{mg} \mathrm{L}^{-1}+9 \mathrm{mg} \mathrm{L}^{-1}\right)$; ácido giberélico + cinetina $\left(5 \mathrm{mg} \mathrm{L}^{-1}+9 \mathrm{mg} \mathrm{L}^{-1}\right)$; ácido indolbutírico + cinetina $\left(5 \mathrm{mg} \mathrm{L}^{-1}+9 \mathrm{mg} \mathrm{L}^{-1}\right)$; ácido giberélico + ácido indolbutírico + cinetina $\left(5 \mathrm{mg} \mathrm{L}^{-1}+5 \mathrm{mg} \mathrm{L}^{-1}+9 \mathrm{mg} \mathrm{L}^{-1}\right) \mathrm{e}$ Stimulate $^{\circledR}\left(100 \mathrm{~mL} \mathrm{~L}^{-1}\right)$. As plantas do controle foram pulverizadas com água. Stimulate ${ }^{\circledR}$ é uma formulação comercial líquida contendo uma combinação de cinetina ( $\left.90 \mathrm{mg} \mathrm{L}^{-1}\right)$, ácido giberélico $(50 \mathrm{mg}$ $\left.\mathrm{L}^{-1}\right)$ e ácido indolbutírico $\left(50 \mathrm{mg} \mathrm{L}^{-1}\right)$. Foram analisadas as variáveis: massa seca da parte aérea $(\mathrm{g})$ e das raízes $(\mathrm{g})$, massa fresca $(\mathrm{g})$ e massa seca $(\mathrm{g})$ dos frutos e o tamanho dos frutos $(\mathrm{cm})$. O delineamento experimental foi inteiramente casualizado com nove tratamentos e quinze repetições. As médias dos tratamentos foram comparadas pelo teste Tukey. A aplicação conjunta de ácido giberélico, ácido indolbutírico e cinetina ou de Stimulate ${ }^{\circledR}$ promoveu incrementos significativos sobre o acúmulo de matéria seca nas raízes e nas massas de matéria fresca e seca dos frutos com relação ao controle. Com a perspectiva de extender tais resultados para a produção comercial de tomate, a relavancia do conhecimento das interações hormonais apresentadas pelos resultados obtidos é discutida.

Palavras-chave: Solanum lycopersicum, balanço hormonal, reguladores vegetais, interações hormonais.

(Recebido para publicação em 15 de setembro de 2012; aceito em 26 de setembro de 2013)

(Received on September 15, 2012; accepted on September 26, 2013)

I: tis long known that different chemicals can act as signals controlling plant growth and development. By the second half of the nineteenth century, the botanist Julius Sachs initiated studies suggesting that plants and their organs growth and development were controlled by substances of localized distribution and specific action, which were subjected to environmental conditions. Such substances are now classified as plant hormones, defined as organic compounds, non-nutrients produced in plants, which are able to promote, inhibit or to modify morphological and physiological processes of the plant, even at very low concentrations $\left(10^{-5}-\right.$ $\left.10^{-4} \mathrm{M}\right)$ (Castro, 1998). Until recently, only six types of plant hormones were considered: auxins, gibberellins, cytokinins, retarders, inhibitors and ethylene. Today, however, other molecules with similar effects have been discovered, such as brassinosteroids, strigolactones, jasmonic acid, salicylic acid and polyamines (Santner \& Estelle, 2009).

Growth regulators or plant growth regulators (PGR's) are organic compounds, natural or synthetic, which exogenously applied in small quantities, have similar actions to those of plant hormones (Caldas et 
al., 1990). Bioregulator is an organic non-nutrient compound that promotes, inhibits or modifies morphological and physiological processes of the plant when applied at low concentrations (Castro et al., 2009).

These substances can be applied directly on plants (leaves, fruits, seeds) causing changes in structural and functional processes, in order to increase production, improve quality and facilitate harvesting. The PGR's regulated some processes in plants, such as germination, rooting, flowering, fruiting and senescence (Castillo et al., 2005).

Although plant growth regulators have extensively been used with the aim to increase crop productivity, a large variation in results still persists, probably due to specific environmental conditions and farming practices employed. Moreover, it is known that plant hormones rarely act alone. Thus, even when a response in the plant is attributed to the action of a plant regulator alone, the tissue receiving the application contains endogenous hormones that contribute to the outcome (Castillo et al., 2005; Castro et al., 2009).

It is often discussed whether plant hormones act independently, however the interrelationships in plant development result from the combination of many signals, of second messengers and of the combined action of many of these substances. Studies on intact plants or isolated plant tissues have evidenced the existence of synergistic, antagonistic and additive interactions between two or more plant hormones (Castro et al., 2009).

Auxins and cytokinins act synergistically to regulate cell division and antagonistically to control buds formation and lateral roots, suggesting multiple mechanisms of interaction (Coenen \& Lomax, 1997). The auxin and gibberellin control separate processes that, when combined, contribute to stem elongation and fruit set (including ovary growth), suggesting an additive effect, in which the auxin stimulates growth by cell expansion and cell division while gibberellin acts in the expansion as well as in the number of cells (Yang et al., 1996).

Valio \& Schwabe (1978) observed a negative interaction between gibberellin and cytokinin on elongation of the bean stem. Leite et al. (2003) also noted that these two plant regulators, when applied separately, promoted stem elongation of soybean plants; however, when applied together, cytokinin inhibited the effects of gibberellin, reducing the size of the plants, which showed a decrease in the number of nodes, stem diameter, leaf area and dry matter production, with no effect on the number of leaves, shoots and root dry matter.

The Micro-Tom cultivar was proposed by Meissner et al. (1997) as a genetic model because of its small size $(8 \mathrm{~cm})$ and short life cycle (70 to 90 days). The tomato 'Micro-Tom', as well as mutants in this genetic background, showing changes in metabolism and sensitivity to different classes of plant growth regulators, is an advantageous model to study the different classes of plant growth regulators and their interactions.

Sirtoli et al. (2008) and Choudhury et al. (2013) proved that the isolated or combined PGR's show different responses in biometrical and productive parameters in Solanum lycopersicum. But there is no scientific evidence in literature about the use of Stimulate ${ }^{\circledR}$ on development of tomato plants.

The aim of this study was to evaluate the effect of isolated and combined application of $\mathrm{GA}_{3}$ (gibberellin), IBA (auxin) and KIN (cytokinin) on the vegetative and reproductive development of tomato plants (Solanum lycopersicum, cv. Micro-Tom) to better understand the interaction between these hormonal classes.

\section{MATERIAL AND METHODS}

Seedlings of cultivar Micro-Tom tomato (Solanum lycopersicum) were planted in small pots of $150 \mathrm{~mL}$, containing a mixture (1:1 ratio) of vermiculite and Plantmax ${ }^{\circledR}$, lime and nitrogen, phosphorus and potassium. The pots were kept in a greenhouse, under an irrigation channel system, from September 16 to December 8, 2009.
The following treatments were sprayed three times on tomato plants, at one-week interval, with one spray during the growing season and twice during the flowering: $\mathrm{GA}_{3}\left(5 \mathrm{mg} \mathrm{L}^{-1}\right)$; IBA ( $\left.5 \mathrm{mg} \mathrm{L}^{-1}\right)$; KIN (9 mg L-1); $\mathrm{GA}_{3}+$ IBA $\left(5 \mathrm{mg} \mathrm{L}^{-1}+5 \mathrm{mg} \mathrm{L}^{-1}\right), \mathrm{GA}_{3}+\mathrm{KIN}$ $\left(5 \mathrm{mg} \mathrm{L}^{-1}+9 \mathrm{mg} \mathrm{L}^{-1}\right)$; IBA $+\mathrm{KIN}(5 \mathrm{mg}$ $\left.\mathrm{L}^{-1}+9 \mathrm{mg} \mathrm{L}^{-1}\right), \mathrm{GA}_{3}+\mathrm{IBA}+\mathrm{KIN}(5 \mathrm{mg}$ $\left.\mathrm{L}^{-1}+5 \mathrm{mg} \mathrm{L}^{-1}+9 \mathrm{mg} \mathrm{L}^{-1}\right)$ and Stimulate ${ }^{\circledR}$ $\left(100 \mathrm{~mL} \mathrm{~L}^{-1}\right)$. The control plants were sprayed with water.

Stimulate $^{\circledR}$ is a commercial liquid formulation with a combination of N6-furfuryladenine (90 $\left.\mathrm{mg} \mathrm{L}^{-1}\right)$ a molecule of citokinin group; (3S, 3aS, 4S, 4aS, 7S, 9aR,9bR, 12S)7,12-dihydroxy-3-methyl-6-methylene2-oxoperhydro-4a,7-methano-9b,3propeno [1,2-b]furan-4-carboxylic acid (50 $\left.\mathrm{mg} \mathrm{L}^{-1}\right)$ a molecule of gibberelin group and 4-(indol-3-yl)butyric acid $\left(50 \mathrm{mg} \mathrm{L}^{-1}\right)$ a molecule of auxin group.

Before flowering, the dry matter of shoots and roots were determined to get the relationship between them. The fresh matter and dried matter of fruits and fruit size were evaluated at harvest.

The experimental design was completely randomized with nine treatments and fifteen repetitions. The data were subjected to the F test to assess the treatment effects on the parameters evaluated. The means were compared by Tukey's test at $5 \%$.

\section{RESULTS AND DISCUSSION}

Longer internodes and delayed flowering were observed in plants treated with $\mathrm{GA}_{3}$ alone (Figure 1). Taiz \& Zeiger (2009) reported that by promoting cell growth and division, the gibberellin stimulates elongation of internodes. The plants treated with IBA alone showed no axillary buds (apical dominance). This phenomenon which is contrary to that observed in plants treated with kinetin (see below), is commonly associated with auxin.

The plants treated with kinetin alone presented reduced internodes and excessive stimulus to the development of lateral buds (Figure 1).

The results in Table 1 show that when the indolbutyric acid was present, 
Table 1. Shoot and root dry matter, dry and fresh matter of fruit and fruit size of tomato cv. Micro-Tom treated with different plant growth regulators (massa seca da parte aérea e radicular, massa seca e fresca dos frutos e tamanho do tomate cv. Micro-Tom tratados com diferentes reguladores vegetais). Piracicaba, ESALQ, 2009.

\begin{tabular}{lccccc}
\hline Treatments & $\begin{array}{c}\text { Shoot dry matter } \\
(\mathbf{g})\end{array}$ & $\begin{array}{c}\text { Root dry matter } \\
(\mathbf{g})\end{array}$ & $\begin{array}{c}\text { Fruits fresh matter } \\
(\mathbf{g})\end{array}$ & $\begin{array}{c}\text { Fruits dry matter } \\
(\mathbf{g})\end{array}$ & $\begin{array}{c}\text { Fruit size } \\
(\mathbf{c m})\end{array}$ \\
\hline Control & $9.65 \mathrm{a}$ & $0.11 \mathrm{c}$ & $39.27 \mathrm{cde}$ & $4.65 \mathrm{~d}$ & $1.76 \mathrm{abc}$ \\
$\mathrm{GA}_{3}$ & $7.00 \mathrm{abc}$ & $0.17 \mathrm{bc}$ & $47.10 \mathrm{ab}$ & $13.55 \mathrm{ab}$ & $1.70 \mathrm{bc}$ \\
$\mathrm{IBA}$ & $5.67 \mathrm{bc}$ & $0.18 \mathrm{abc}$ & $46.35 \mathrm{abc}$ & $8.14 \mathrm{~cd}$ & $1.89 \mathrm{abc}$ \\
$\mathrm{KIN}$ & $9.06 \mathrm{ab}$ & $0.11 \mathrm{c}$ & $42.45 \mathrm{bcd}$ & $8.25 \mathrm{~cd}$ & $1.85 \mathrm{abc}$ \\
$\mathrm{GA}_{3}+\mathrm{IBA}$ & $4.90 \mathrm{c}$ & $0.22 \mathrm{abc}$ & $38.37 \mathrm{de}$ & $9.71 \mathrm{bc}$ & $1.83 \mathrm{abc}$ \\
$\mathrm{GA}_{3}+\mathrm{KIN}$ & $6.36 \mathrm{abc}$ & $0.18 \mathrm{bc}$ & $34.62 \mathrm{e}$ & $13.65 \mathrm{ab}$ & $1.66 \mathrm{e}$ \\
$\mathrm{IBA}+\mathrm{KIN}$ & $6.27 \mathrm{c}$ & $0.16 \mathrm{bc}$ & $43.75 \mathrm{bcd}$ & $13.34 \mathrm{ab}$ & $2.13 \mathrm{ab}$ \\
$\mathrm{GA}_{3}+\mathrm{IBA}+\mathrm{KIN}$ & $3.11 \mathrm{c}$ & $0.35 \mathrm{a}$ & $51.45 \mathrm{a}$ & $15.75 \mathrm{a}$ & $2.16 \mathrm{a}$ \\
$\mathrm{Stimulate}^{\circledR}$ & $3.54 \mathrm{c}$ & $0.35 \mathrm{a}$ & $51.70 \mathrm{a}$ & $15.00 \mathrm{a}$ & $2.17 \mathrm{a}$ \\
\hline $\mathrm{F}($ treat) & $6.86 * *$ & $5.50 * *$ & $13.23 * *$ & $17.17 * *$ & $4.56 * *$ \\
$\mathrm{CV}(\%)$ & 30.64 & 40.55 & 8.98 & 19.70 & 11.89 \\
\hline
\end{tabular}

Means followed by the same letter within a column do not differ in the Tukey test at 5\% probability (médias seguidas por mesma letra na coluna não diferem significativamente entre si pelo teste Tukey a $5 \%$ de probabilidade); ** significant at $1 \%$ probability by $\mathrm{F}$ test (**significativo a $1 \%$ de probabilidade pelo teste $\mathrm{F}$ ). $\mathrm{GA}_{3}=$ gibberellic acid (ácido giberélico); $\mathrm{IBA}=$ indolbutyric acid (ácido indolbutírico); $\mathrm{KIN}=$ kinetin (cinetina).

alone or combined with two other growth regulators, there was an increase of the root dry matter in relation to that of shoots where dry matter was decreased. This change in the sourcesink relationship suggests that IBA increases the ability of carbohydrates to transport to the root system due to the concentration of auxin applied. It is generally assumed that the greater ability of indolbutyric acid to promote rooting, as compared with other auxins, is because of its relatively higher stability. Indolbutyric acid is transported predominantly in a basipetal direction in plant tissues (Epstein \& Ludwig-Müller, 1993).

Only the synergistic effect of three growth regulators $\mathrm{GA}_{3}$, IBA and KIN or Stimulate ${ }^{\circledR}$ was able to promote increases in the root system differ from that of the control (Table 1). In the application of IBA to cuttings of several plants, most of the auxin remained at the basis of the cuttings. The higher rooting promotion of IBA was also related to the fact that its level remain elevated longer than that of indole-3-acetic acid, even though the auxin is metabolized in the tissue (Epstein \& Ludwig-Müller, 1993).

The fresh matter of tomato fruits 'Micro-Tom' was also increased significantly as a result of the synergism between the three growth regulators $\left(\mathrm{GA}_{3}, \mathrm{IBA}\right.$ and KIN or Stimulate $\left.{ }^{\circledR}\right)$, and the application of gibberellic acid alone also increased this parameter in relation to the control group. In tomato fruits the increasing doses of gibberellic acid $(0 ; 30 ; 60 ; 90$ and $120 \mathrm{ppm})$ showed the linear model for fresh matter, diameter and length, indicating that the gibberellin has the potential to increase the size of the fruit of tomato (Ayub \& Rezende, 2010).

The fruit dry matter was higher in treatment with the three growth regulators $\left(\mathrm{GA}_{3}\right.$, IBA and $\mathrm{KIN}$ or Stimulate ${ }^{\circledR}$ ), and for this parameter, treatments with $\mathrm{GA}_{3} ; \mathrm{GA}_{3}+\mathrm{KIN}$; IBA $+\mathrm{KIN} ; \mathrm{GA}_{3}+$ IBA also differed from the control (Table 1). Both auxin and cytokinin interact in a complex manner to control many aspects of growth and differentiation. The two plant hormones act synergistically to regulate cell division, and antagonistically to control lateral bud or root outgrowth. The manipulation of cytokinin levels in plants by exogenous application results in more auxin. Removal of endogenous auxin source, leads to a large increase in the cytokinin content of xylem exudates. This effect of auxin on cytokinin concentrations in the xylem suggests that auxin can influence apical dominance via inhibition of cytokinin synthesis or export from the roots (Coenen \& Lomax, 1997). It is suggested that in intact pea plants, auxin from the apical bud moves into the elongating internodes where it maintains GA biosynthesis (Ross et al., 2000).

The use of three plant growth regulators $\left(\mathrm{GA}_{3}\right.$, IBA and $\left.\mathrm{KIN}\right)$ increased the development when compared to control (Figure 1). The application of Stimulate ${ }^{\circledR}$ and IBA + KIN increased fruit size as compared to the application of $\mathrm{GA}_{3}+\mathrm{KIN}$ treatment (Table 1).

The Figure 1 clearly shows the effects caused by the application of growth regulators: i) $\mathrm{GA}_{3}$ stimulates elongation of internodes; ii) IBA applied alone, showed no lateral buds (apical dominance); iii) KIN applied alone, did not present significant differences related to the control; iv) the combined growth regulators promoted a blend of the effects mentioned above.

When applied in pairs, $\mathrm{GA}_{3}+\mathrm{IBA}$; $\mathrm{GA}_{3}+\mathrm{KIN}$; and IBA + KIN or the three altogether $\left(\mathrm{GA}_{3}+\mathrm{IBA}+\mathrm{KIN}\right.$ or Stimulate ${ }^{\circledR}$ ), it appears that there is a combination of the effects of each of plant growth regulators to promote a more balanced shoot development (Figure 1); similar results were reported 

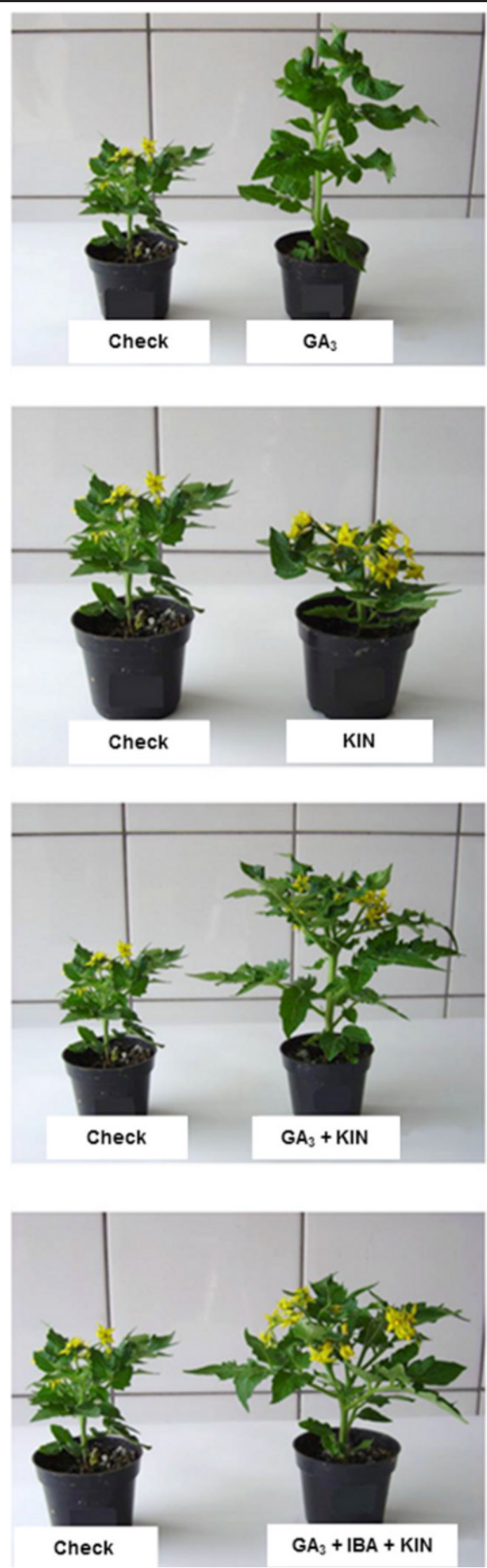
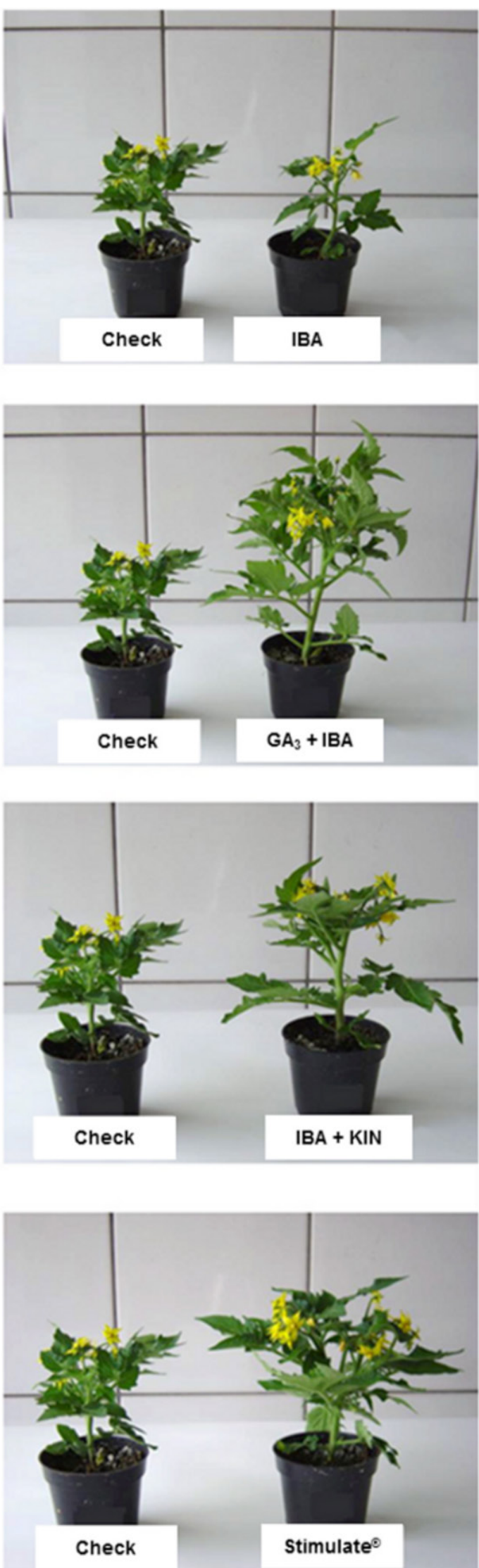

Figure 1. Development and flowering of tomato 'Micro-Tom' submitted to different treatments with plant growth regulators and compared to the control (desenvolvimento e florescimento de tomate 'Micro-Tom' submetidos a diferentes tratamentos com reguladores vegetais e comparados ao controle). Piracicaba, ESALQ, 2009. 
by Choudhury et al. (2013), in tomato plants subjected to gibberellic acid and 4-chloro phenoxy acetic acid, when applied alone or associated, which resulted in increases in crop production.

This work points to the possibility of future studies to assess morphological changes in plant tissues treated with plant growth regulators, as well as on changes in the shoot and root structures.

The conclusions are that the combined application of $\mathrm{GA}_{3}$, IBA and KIN or Stimulate ${ }^{\circledR}$ promote significant increases in the dry matter accumulation in roots and fresh and dry matter of fruits of tomato 'Micro-Tom' in relation to control.

\section{ACKOWLEDGEMENTS}

This article is part of the doctoral thesis of the first author thanking ESALQ the availability of its dependencies.

\section{REFERENCES}

AYUB RA; REZENDE BLA. 2010. Contribuição do ácido giberélico no tamanho de frutos do tomateiro. Biotemas 23: 25-28.

CALDAS LS; HARIDASAN P; FERREIRA ME. 1990. Meios nutritivos. In: TORRES AC; CALDAS LS (eds). Técnicas e aplicações da cultura de tecidos de plantas. Brasília: ABCTP/Embrapa-CNPH, p. 37-70.

CASTILLO OC; BARRAL G; RODRÍGUEZ GE; MIGUELISSE NE; AGÜERO MS. 2005. Establecimiento y desarrollo en el cultivo forzado de tomate: efecto de fitoreguladores. Revista de la Facultad de Ciencias Agrarias UNCuyo 37: 83-91.

CASTRO PRC. 1998. Utilização de reguladores vegetais na fruticultura, na olericultura e em plantas ornamentais. Piracicaba: DIBDESALQ, (Série Produtor Rural), 92p.

CASTRO PRC; SERCILOTO CM; PEREIRA MA; RODRIGUES JLM; ROSSI G. 2009. Agroquímicos de controle hormonal, fosfitos e potencial de aplicação dos aminoácidos na agricultura tropical. Piracicaba: DIBDESALQ, (Série Produtor Rural) 83p.

CHOUDHURY S; ISLAM N; SARKAR MD; ALI MA. 2013. Growth and yield of summer tomato as influenced by plant growth regulators. International Journal of Sustainable Agriculture 5: 25-28.

COENEN C; LOMAX TL. 1997. Auxin-cytokinin interactions in higher plants: old problems and new tools. Trends in Plant Science 2: 351-356.

EPSTEIN L; LUDWIG-MÜLLER J. 1993. Indole3-butyric acid in plants: occurrence, synthesis, metabolism and transport. Physiologia Plantarum 88: 382-389.
LEITE VM; ROSOLEM CA; RODRIGUES JD. 2003. Gibberellin and cytokinin effects on soybean growth. Scientia Agricola 60: 537-541.

MEISSNER R; JACOBSON Y; MELAMED S; LEVYATUV S; SHALEV G; ASHRI A; ELKIND Y; LEVY A. 1997. A new model system for tomato genetics. The Plant Journal 12: 1465-1472.

ROSS JJ; O'NEILL DP; SMITH JJ; HUUB L; KERCKHOFFS J; ELLIOTT RC. 2000. Evidence that auxin promotes gibberellin $\mathrm{A}_{1}$ biosynthesis in pea. The Plant Journal 21: 547-552.

TAIZ L; ZEIGER E. 2009. Fisiologia Vegetal. 4 ed. Porto Alegre: Artmed, 819p.

SANTNER A; ESTELLE M. 2009. Recent advances and emerging trends in plant hormone signalling. Nature 459: 1071-1078.

SIRTOLI LF; CERQUEIRA RC; FERNANDES LMS; RODRIGUES JD; GOTO R; MEDEIROS MO. 2008. Resposta a aplicação de diferentes reguladores vegetais em mudas enxertadas de tomateiro. Biodiversidade 7: 29-36.

VALIO IFM; SCHWABE WW. 1978. Correlative growth in seedlings of Phaseolus vulgaris L.: inhibition of stem growth by the primary leaves. Annals of Botany 42: 263-268.

YANG T; DAVIES PJ.; REID JB. 1996. Genetic dissection of the relative roles of auxin and gibberellin in the regulation of stem elongation in intact light-grown peas. Plant Physiology 110: 1029-1034. 